\title{
Role of the Energy in Modern Society
}

ISSN Print: 2576-0556

\author{
Siniša Franjić \\ Independent Researcher, Croatia.
}

How to cite this paper: Siniša Franjić. (2021) Role of the Energy in Modern Society. Journal of Humanities, Arts and Social Science, 5(1), 157-165.

DOI: $10.26855 /$ jhass.2021.01.016

Received: April 17, 2021

Accepted: May 12, 2021

Published: June 2, 2021

*Corresponding author: Siniša Franjić, Independent Researcher, Croatia. Email: sinisa.franjic@gmail.com

\begin{abstract}
One of the main issues of energy policy is the risk of mismatch between supply and demand. Some countries establish a clear and unambiguous energy policy, while others do not. Nevertheless, each country applies some kind of energy policy. Governmental or intergovernmental bodies can use economic and energy modeling as advisory or analytical tools. Energy policy debates are often dominated by price concerns, which necessitates a transparent public debate on energy costs and prices. It should be noted that energy from renewable sources has very low external costs, which is very different from conventional energies, which pass on to today's society and future generations a significant part of health and environmental costs. Clear and comprehensive information should be publicly available to create a complete picture of the costs and benefits associated with subsidies provided for renewable energy sources, fossil fuels and nuclear energy, including external costs arising from effects on human health and the quality of the environment, such as and the benefits arising from the abolition of imports and from energy security.
\end{abstract}

Keywords

Energy, Economy, Policy, Environment

\section{Introduction}

Promoting energy efficiency is one of EU energy law's most important objectives and is an essential component of the instruments used to promote sustainable development (Talus, 2016). By reducing and intensifying energy consumption, the other objectives of EU energy policy, such as security of supply (because less external energy is needed) and sustainability (emissions are reduced because less energy is consumed), can also be addressed.

Energy saving was brought to the table from the 1970s oil crisis onwards, and was in the early days connected with high energy prices. In those days, energy savings relied essentially on the demand side: the reduction of energy consumption offered a logical means of reducing the energy shortfall and promoting energy security. Thus, energy saving and energy efficiency are obvious primary areas of action for the EU.

These two concepts are often used synonymously. However, while the concept of energy saving relates directly to the idea of saving energy (i.e. reducing consumption to ensure security of supply especially in times of shortage), energy efficiency has more of a 'green' meaning. Thus, the concept of energy efficiency already includes a trace of environmental protection. Yet, the two concepts are closely intertwined today by both environmental and security-of-supply objectives, since energy efficiency must also be seen to improve energy security benefits especially by lowering fossil fuel use and thus imports from third countries.

\section{Energy Security}

Energy security and climate change are therefore 'hot topics' in the external relations of the EU and its individual Member States (Kamphof et al., 2017.). The Paris Climate Change Agreement of 2015 has firmly and urgently 
established the reduction of greenhouse gas emissions and, hence, the 'decarbonization' of the world economy as a global policy objective to be achieved in the next few decades. The EU has been very active in setting a (global) climate agenda and the Paris Agreement has been hailed as a success of EU climate diplomacy. At the same time, the EU is currently to a large degree dependent on (fossil) energy imports and faces related challenges in achieving energy security (security of supply) and ensuring affordability of energy in the shorter and longer term. The EU is the biggest energy customer in the world, depending on 'a very sparse number of energy suppliers' who could use this situation as a 'political weapon'. Both climate and energy policy are areas of 'shared competences' between the EU and its Member States. As a result, both the relevant European institutions and the Member States engage in energy diplomacy and policy-making externally, that is, on the international stage.

Countries' definition of energy security has much to do with their own particular energy situation and how they view their vulnerabilities to energy supply disruptions (Luft et al., 2009). In this, it is important to realize that there are two primary energy usage sectors that pose two different types of energy security challenges. The first sector is electricity. Throughout the world today electricity is generated from coal (41\%), natural gas (20.5\%), renewables like hydroelectric, biomass, solar, wind and geothermal power (18.5\%) and nuclear power (15\%). Contrary to popular belief, in most countries electricity is essentially no longer produced from oil. Only 5 percent of world electricity is made from petroleum. According to the 2007 International Energy Outlook of the Energy Information Administration, by 2030 oil's share of global power generation will drop to 3.8 percent while coal's share, despite all the concerns about global warming, is projected to climb to 44 percent. This diversity of sources does not exist in the second major sector of energy use - transportation. Transportation energy makes the world go around. It enables the free flow of goods and services onboard cars, trucks, trains, ships and airplanes. Here oil is king, responsible for over 95 percent of the energy used in this sector. In fact, the vast majority of the cars sold around the world today cannot even run on something other than petroleum, in the form of gasoline or diesel.

Europe is not energy-rich, but fortunate enough to be bordering with four regions that are well-endowed with natural resources (Proedrou, 2012). Proximity with the Middle East, North Africa, Russia and the North Sea facilitates energy trade between these regions and the EU. The EU's well developed and lucrative market remains attractive for exporters, not least since EU Members pay high prices and in hard currency, while most of the exporters depend for their survival and prosperity on energyborn revenues. On the other hand, however, the particularities of the global energy market, such as transportation safety hazards, hiked prices that may hold growth down, resource nationalism and unreliable suppliers, as well as the monopolistic role of OPEC, are all relevant risks for the EU. For these reasons, although the EU is able to secure adequate supplies, the danger of supply shortages at any time in the future can and should not be downplayed. In addition, it is questionable for how long the EU should remain dependent on fossil fuels in the face of mounting environmental degradation and progressively depleting resources.

\section{Energy and Economy}

The use of commercial fuel drives the economies of the world (Richter, 2010). Countries using the least energy per capita have the least income per capita and their people are the poorest. Countries using the most energy per capita have the largest incomes per capita and their people are the richest. The poor want to grow rich, the rich want to grow richer, and so energy consumption everywhere in the world continues to rise.

The very poorest countries are not now relevant to world energy demand or to the greenhouse gas emissions that drive climate change. There are about 1.6 billion people who have no access to any form of commercial energy. If they were magically given enough to run a refrigerator, light their homes at night, and run their schools, the added energy required would amount to only about $1 \%$ of the world's energy consumption. These countries will begin to have an impact on energy demand and climate only when their economies grow enough to make a difference. Until then, they should be left to increase the well-being of their citizens in the most effective way they can without regard to global climate issues. Of course they have to be careful about their local environment, but mandated greenhouse gas reductions should not be required of them.

Energy intensity is a measure of efficiency and of the product mix in a particular economy. Energy intensity usually drops as an economy matures, largely because of a shift from manufacturing to services (it takes much less energy to run a bank than a steel mill, though both may produce the same increment of GDP). This is particularly important because two of the world's largest countries by population, China and India, are undergoing rapid economic growth. At the beginning of their growth cycles, industry dominates over services and processes tend to be relatively inefficient. The effects of improving efficiency (reducing energy intensity) on energy demand are also 
important in estimating the worldwide demand for energy in the future.

Energy is a capital-intensive industry, and as a $\$ 6$ trillion global business, the largest industry in the world (Fusaro, 2010). Its transformation to a more energy efficient and environmentally benign industry will take decades. Today, we are at a turning point in the energy world as emerging environmental regulation on climate change and governmental mandates on both renewable energy and energy efficiency proliferate throughout the world. The energy industry will rise to the environmental challenge through both technology and engineering solutions as it has throughout the past forty years of environmental rules. It will require more capital to be invested into this emerging sector. Most importantly, energy finance will also change. Besides funding for oil, gas, and coal production projects, there will be new business opportunities in both renewable energy and clean energy technology. Change will be incremental, but will accelerate throughout both the developed and developing worlds. But there clearly will be a need for fossil fuels for many more decades. The changes in financial markets in coming years will be more fundamental than many realize.

Efficient use of energy in the generation, transmission and final energy is the basis of development guidelines of all sectors of the energy system (Franjić, 2017). In the sector of oil, petroleum products and natural gas, energy efficiency is reflected in the modernization of refineries and the use of improved technologies for the exploitation of oil fields and gas. In the electric power industry, energy efficiency involves the application of more efficient technologies for energy conversion, such as: advanced technology of coal combustion, gas power plants and high-efficiency cogeneration of heat and power and the reduction of losses in transmission and distribution network, favorable location and building incentives for distributed generation of electricity. Regarding the production of thermal energy, the development of district heating systems is directed towards increasing the efficiency of energy conversion, application of cogeneration units and reduce the loss of heat energy distribution, distributed energy production and use of renewable energy sources.

Energy economics combine production, distribution and use of energy by societies (Weber, 2018). By that it is strongly related to energy engineering, politics, ecology, economy, etc. As such several disciplines nowadays come on focus while debating energy economic issues: climate change and policy, sustainability, risk analysis, security of supply, energy audits and energy efficiency, energy policy, energy management, specialization on energy services, e-mobility and sustainable transport, renewable energies, load management to name the mostly used terms.

Climate change became to be one of the key words today and will be even more important in the very close future. The global warming effect is increasing, undoubtable being pushed also by the energy use and green-house gas emissions worldwide.

The human influence was confirmed in the heating of the oceans and the atmosphere, the changes in the global water cycles, the rise of the global average sealevels as well as the decreasing levels of snow and ice on earth. As a consequence the IPCC (Intergovernmental Panel on Climate Change) claims a 100\% resignation from the use of any fossil energy sources.

\section{Energy Policy}

The modern lifestyle involves increasing use of energy in order to achieve increasing efficiency and comfort and energy use is growing every day (Franjić, 2015). Today, most of the energy needs of mankind settled using very harmful fossil fuels, and in the future will be the fuel to be replaced with cleaner sources of energy in the form of renewable energy sources or nuclear power. In the future, renewable energy sources will become the primary, and the energy needs of humanity will get bigger. That modern style of life have intention to be important part of strategy of economic development.

Increasing energy import dependency and limited success in achieving diversification, high and fluctuating energy prices, growing demand, security risks associated with transport routes, climate change, the need to liberalize the energy market, limited coordination factors of energy policy that impedes investment in energy infrastructure and difficulties on the market of oil and gas are just some of the important issues the EU was faced with over time, and the same led to the necessity of creating a common European energy strategy (Franjić, 2016a).

In times of increasing environmental and climate challenges or diplomatic crises, energy issues have repeatedly entered the agendas of policy makers, researchers and society in the European Union under a number of different frames (Biesenbender, 2015). During the last 60 years, EU environmental policy has taken place under changing institutional, environmental and societal conditions. These conditions have influenced both agenda shaping and decision making with regard to the regulation of energy issues. During the first decades of the European int egration process, the main motivation was to secure energy provision in an emerging community of nation-states. Moreover in 
the 1960s, 1970s and 1980s, several attempts were made to design a comprehensive energy policy and to transfer national capacities with regard to energy security to the EU—a topic that has recently gained renewed attention. However, in the absence of any concrete primary law to empower the EU institutions to regulate the energy sectors prior to the mid-1980s, these attempts failed because they did not reach consensus among the member states. Finally in the 1990s, the EU was successful in liberalising the electricity market. However, despite its implications for the common market, energy policy was not defined as an area of priority action by primary (i.e. treaty) law until the passage of the Treaty of Lisbon. Since then, energy policy has ranked high on the EU's political agenda, which has also led to the passage of concrete regulatory decisions. This process was also motivated and shaped by concerns for environmental and climate change. In addition, the mid- and long-term security of energy supplies has been a main driver of the EU's energy policy agenda.

Altogether, the emergence of EU energy policy decisions and their agenda shaping processes have been strongly linked to developments in the international energy markets, the evolution of EU primary law, national policy targets and decisions as well as developments in the environment and climate. Changes in treaty law and problem perception along with new framing opportunities have therefore paved the way for the development of a comprehensive energy policy since the mid-2000s. Shortly thereafter, regulations were passed to extend the agenda-shaping power of the European public through the introduction of the European Citizens' Initiative thereby laying the legal foundations for a smooth interaction between the systemic and the EU's political agendas.

Energy policy in many EU countries has recently focused on the expansion of RES (Renewable Generation Sources) (Perner et al., 2015). Non-dispatchable technologies 18 of wind and solar play a particular role in this. Therefore, RES expansion can raise particular issues in relation to future security of supply especially in relation to (a) volatility of generation and (b) inaccuracies of production forecast.

In relation to (a), volatile and fluctuating generation from wind and solar requires the availability of secured back-up capacities through storage, conventional generation, or demand flexibility that can step in for these renewables. The question is whether market mechanisms alone can deliver these capacities. In relation to (b), inaccuracies in production forecast, the availability of wind and solar radiation can only be predicted with limited accuracy. The availability of respective plants is only known with high certainty shortly (a few hours or less) before real-time dispatch. This holds even though there have been significant improvements in forecasting accuracy in recent years. This uncertainty about actual production requires back-up capacity that needs to be dispatchable at short notice.

\section{Energy Poverty}

Energy is the main strategic resource in developed countries (Franjić, 2018). It has a huge impact on the quality of daily life and every day more and more benefits. It also has a huge impact on the entire social infrastructure and thus is inextricably linked to the growth and development of the economy. However, the economic crisis took its toll, which means that many people have lost their jobs but their opportunities for energy consumption significantly reduced. Energy richness is a proof of modern trends in production, which means that there is also the energy that is produced, for example, through the wind power system and through biological systems. Given the financial situation in which they are, people are not currently able to pay any extra costs or energy.

Energy poverty occurs when a household is unable to secure a level and quality of domestic energy services - space cooling and heating, cooking, appliances, information technology-sufficient for its social and material needs (Bouzarovski, 2018). This somewhat contested and broad definition lies at the tip of a vast scientific and policy iceberg, involving complex socio-technical relations that extend across the planet. Energy poverty affects millions of people worldwide, even if the causes and consequences vary depending on context. Historically, the existence of this condition in the Global North has been attributed to contingencies such as low incomes, energy-inefficient homes and high energy prices, while in the Global South, the infrastructural lack of access to more technologically advanced energy carriers has been seen as the main culprit. It is estimated that more than one billion people across the world suffer from this condition; and it has received significant prominence thanks to high-profile international drives such as the 'Sustainable Energy for All' initiative, aimed at 'reducing the carbon intensity of energy while making it available to everyone on the planet' so as to contribute to a 'cleaner, just and prosperous world for all'.

Energy poverty—lack of access to electricity and dependence on solid biomass fuels for cooking and heating - remains an enduring global problem (Sovacool, 2012). Approximately 1.4 billion people still live without 
electricity, and an additional 2.7 billion people depend entirely on wood, charcoal, and dung for their domestic energy needs.1 Lack of access to modern energy not only limits opportunities for income generation and blunts efforts to escape poverty, it also severely impacts women and children and contributes to global deforestation and climate change. The search for energy fuels and services is therefore an arduous, daily grind for billions of people around the world, most of them in Asia, where serious repercussions of energy poverty assume different forms depending on geographical terrain, population size, and climatic variations.

However, small-scale renewable energy technologies-solar home systems, residential wind turbines, biogas digesters and gasifiers, microhydro dams, and improved cookstoves—offer these households and communities the ability to tackle extreme poverty, enhance gender equality and education, reduce hunger, provide safe drinking water, improve health, and ensure environmental sustainability. Innovative collaborations and programs involving governments as well as businesses, nonprofit organizations, banks, and community based cooperatives have emerged in recent years to expand access to these technologies and the energy services they offer. All over Asia, these burgeoning partnerships have come in different forms: some focus on improving technological performance, others on providing low-cost loans, still others leasing out systems according to a "fee-for-service" model. But regardless of their approach, such technologies and the programs that support them can drastically improve living standards for some of the poorest communities in the region.

\section{Climate Change and Energy}

Climate is long-term averages (Haal, 2018). There is a big difference. Today in Massachusetts, USA, the temperature increased by $20^{\circ} \mathrm{F}$ over the course of the day. It was cool and rainy in the morning and hot and muggy in the afternoon. But average temperature across the world is different. Climate scientists John Anderson and Alice Bows conclude that we must keep the increase in average temperature to less than $2^{\circ} \mathrm{C}\left(3.6^{\circ} \mathrm{F}\right)$. For Anderson and Bows, $2^{\circ}$ is not the threshold between safe and dangerous; it is the threshold between dangerous and extremely dangerous. In the developed world, a positive feedback loop has developed. As the temperature warms, more people purchase and use air conditioning. This uses more electricity and puts more carbon into the atmosphere. The planet warms. People use more air conditioning. The planet warms.......... And carbon dioxide emissions continue to increase.

Point of departure is to identify the sources of corporate strategy choice: what factors determine the strategies chosen by the oil industry to meet climate-change challenges (Birger Skjærseth et al., 2003). We explore the impact of three main groups of factors, related to: (1) company-specific features; (2) the political context of corporate activity at the domestic level; (3) the international institutional context in which multinational companies operate. Each of these three clusters of factors forms a focus for one of the three 'models' that will be used to shape the analysis. These are not models in a formal sense, but are rather tools that provide simplified and complementary pictures of the driving forces behind corporate choice at different decisionmaking levels.

The first model, which we have labelled the Corporate Actor (CA) model, is based on contributions from the business environmental management literature. The CA model focuses on factors that can shape a company's climate strategy, with an emphasis on factors such as environmental risk, environmental reputation and organisational learning capacity.

The second model, referred to as the Domestic Politics (DP) model, is based on the assumption that even multinational companies are heavily influenced by the framework conditions of their home-base countries in which they have their historical roots, have located their headquarters and have their main activities. This model is based on theories of state-society relationships and highlights social demands for environmental quality, governmental supply of environmental policy and the political institutions linking demand and supply. Political institutions shape the channels of interaction between industry, governments and other interested parties.

The last perspective is referred to as the International Regime (IR) model. This model takes us from domestic to international politics, and is based on the assumption that the key sources of corporate strategies are found within the context of international regimes rather than in the political context of the companies' home-base countries. Climate change is a global problem, largely caused by global target groups like the oil industry, dealt with within the framework of international institutions. This model is based on international regime approaches and emphasises how international environmental regimes may trigger changes in corporate strategy choice. The main focus of analysis within this perspective, therefore, is changes in corporate strategies over time. This model thus captures the dynamic relationship between multinational corporate actors and international regimes.

In the field of climate change, international law is of prime importance and guides the formulation of regional and 
national law (Pereira et al., 2012). This is because climate change is seen as a transboundary, global problem, to be dealt with globally, regionally and nationally, though the regional and national impacts of climate change may vary. EU level regulation is tightly aligned to the objectives of international agreements. However, though the international community accept that climate change is a global problem, the causes of climate change are very much attributed to the historical emissions in the developed world.

Unlike other major forms of atmospheric pollution, the transboundary scope of greenhouse gas (GHG) emissions is very wide in terms of both the sources of the emissions and their dispersion in the atmosphere. The effects of climate change are felt worldwide and in all economic sectors, requiring the interplay of law and policy at international, European and national levels and the application of 'command-and-control', market-based and other regulatory instruments.

\section{Energy and Environment}

The advent of legislation protecting the environment as a valuable asset in itself is relatively recent worldwide (Fernandes et al., 2015). Initially, environmental issues emerged for economic reasons; that is, forests and fruit trees were protected because of the riches derived from such environmental goods, or the hunting and fishing of certain specimens were protected to maintain their reproductive capacity and ensure their economic benefits. The first legal measures, including international ones, were very specific, considering only economic resources in the protected species.

However, going beyond local environmental impacts, large natural disasters engendered recognition of the need for environmental protection as an integrated system, essential to a healthy quality of life. Thus, the environment came to have a value in itself, to be relevant to society and therefore legally protected, especially through international treaties starting in 1970.

Irrespective of legal protection, it is important to understand that the existence of human life is intricately linked to its surroundings, that is, the environment. Humanity developed with the use of natural resources, the material basis of human action. It is therefore impossible to dissociate "the economic fundamentals of a coherent and practical environmental policy. Moreover, a coherent economic policy does not ignore the need for a policy to protect natural resources”. Indeed, it is impossible to think of development without considering the environmental variable.

\section{Costs of Energy}

The golden age of electric utilities was the period from 1945 to 1965 (Casazza et al., 2003). During this period, there was exponential load growth accompanied by continual cost reductions. New and larger plants were being installed at a continuously lower cost per kilowatt reflecting economics of scale. Improvements in efficiency were being obtained through higher temperatures and pressures for the steam cycle, which was lowering the amount of fuel required to produce a kilowatt hour of electric energy. New generating plants were being located at the mine mouth, where coal was cheap, and power was transmitted to the load centers. This required new, higher-voltage transmission lines since it had been found that "coal by wire" was cheaper than the existing railroad rates.

Energy prices should, as a rule, be determined by an open market (Šimundić et al., 2015). However, the market can only function well in the conditions of a sufficient supply. The energy market has external effects, such as security of supply and environmental impacts. In the area of electricity, natural gas and oil, opportunities for transmission infrastructure will be exploited and development will further be directed towards the creation of conditions for energy transit, which will contribute to a more intensive connection to the energy network and the European Union market (Franjić, 2016b).

The coordination of utilities was extensive. The leaders of the industry involved in planning the power systems saw the great advantage of interconnecting utilities to reduce capital investments and fuel costs. Regional and inter-regional planning organizations were established. The utilities began to see the advantage of sharing risk by having jointly owned units.

On the analytical side, improved tools were rapidly being developed. Greatly improved tools for technical analysis—such as computers-began to appear, first as analog computers and then as digital computers. At the same time, the first corporate models were developed for analyzing future plans for possible business arrangements for joint projects, of costs to the customers, for the need for additional financing, and the impact on future rates.

All of these steps reduced capital and fuel costs which resulted in lower rates. Everyone was happy. The customers were happy because the price of electricity was going down. The investors were happy because their returns on 
investments and the value of their stock were increasing. The system engineers were happy because they were working on interesting and challenging problems that were producing recognized benefits, and their value to the utility organizations was increasing. Finally, the business mangers were happy that they were running organizations that were functioning smoothly and were selling their product to satis fied customers.

New power generation facilities, new transmission lines, new gas pipelines-these are expensive propositions (Huber, 2018). As energy policy makers debate various aspects of energy policy, it is worth paying attention to how policy makers plan to pay for the upcoming overhaul. Every bit as important as the raw physical technology of energy is the way that societies foot the bill for it, for the way that costs are borne will have important consequences.

What sorts of consequences? First, and most importantly, infrastructure simply will not be built if no way can be found to pay for it. In most Western economic sectors, the market organizes capital investment. We tend to assume that if there is sufficient demand for something, market forces will provide it: new cars, new toys, new books make their way into the marketplace as if automatically, conjured into existence by the "invisible hand". But in these instances, investment is premised on a prospective revenue stream that will flow between buyers and sellers in market transactions. In other sectors, however including energy-market forces are channeled and constrained by governmental intervention. Certain kinds of infrastructure would almost certainly be underdeveloped but for state action. Regulators are involved at every part of the energy system, from the extraction of natural resources to the generation of energy to its distribution and eventual sale to end users. Thus, the organization of massive expenditures is a much more public and political process than in most other contexts. Paying for infrastructure requires political agreement on not only the target of investment but also the means of bearing its costs. This agreement can be dif ficult to achieve.

Subtler are the systemic consequences of individual decisions about paying for energy. Many energy investments, whether in energy efficiency or distributed generation, are cost-effective overall but entail high up-front costs. Research demonstrates that consumers irrationally avoid such up-front costs, with signficant implications for the build-out of energy infrastructure. A great deal of work has been devoted to understanding this problem and solving it with public policy.

Similarly, when a mode of payment has been identified and agreed upon-when paying for infrastructure is "easy"- there can be unintended consequences. Widespread political acceptance of the basic utility model, in which utilities pass along capital costs to captive ratepayers, almost certainly led to an overinvestment in certain forms of energy infrastructure. Similarly, congressional "logrolling” practices in the United States kindled the era of "big hydro", a dam-building spree that brought cheap hydropower but also ecological devastation. Many dams in America are now being torn down as their environmental consequences become known. Moreover, just as consumers sometimes find themselves "stuck" with outdated devices, so too do utilities sometimes find themselves saddled with infrastructure that impedes their flexibility later. Infrastructure is durable, so investment decision reverberates into the future for years to come.

Energy futures and options contracts and markets provide many benefits to market participants and the public at large (Errera et al., 2002). One of the most important benefits is a highly visible and efficient price discovery mechanism. Futures contracts trade under conditions that closely approximate perfect competition; there are a large number of buyers and sellers conducting transactions in a homogenous product. Exchange rules prevent manipulation and ensure fair, open, and honest trading. In addition, there is an efficient and essentially costless information system, and except for financial responsibility there are no barriers to entry into the market. Under such conditions the price which results can be considered to be the "proper" price in the sense that it represents the consensus results of the decisions of many thousands of independent market participants.

Prior to the advent of energy futures markets there was no visible, widely quoted benchmark price. Often those prices quoted were subject to modifications and discounts which rendered them useless in making decisions. OPEC-posted prices were often subject to political as well as supply and demand considerations. Different major oil companies would often sell product to their customers at substantially different prices. In addition, the cash energy prices quoted in one market are usually not representative of prices in other geographic locations.

Futures prices are not subject to the problems of posted and spot market prices. Futures prices are determined in a central marketplace and are representative of standardized quantities and qualities of petroleum product trading at a particular location (the delivery point of the contract). Cash prices of product of different quality may be established by using this benchmark price plus or minus an appropriate quality differential. Similarly, the benchmark may be used to establish cash prices in different locations with the use of transportation differentials. This objective benchmark information is useful even for those who are not participating in the cash market. Futures quotes are 
available worldwide on a daily basis in newspapers and instantaneously via electronic media.

\section{Conclusion}

Provided that appropriate regulatory conditions exist, civil society has a strong interest and potential to implement most of the transition to decentralized, sustainable energy production. Civil society participants recognized this business opportunity and showed a very high interest in participating in renewable energy production with the aim of generating income and retaining value in local communities. Renewable energy projects have often been a central element of community initiatives and bring much broader social, economic and environmental benefits from energy production itself as they encourage collaboration, social innovation, education, improved local services and creating new jobs.

\section{References}

Biesenbender, S. (2015). “The EU’s Energy Policy Agenda: Directions and Developments” in Tosun, J., Biesenbender, S., Schulze, K. (eds): “Energy Policy Making in the EU—Building the Agenda”, Springer-Verlag, London, UK, pp. 21-22.

Birger Skjærseth, J., Skodvin, T. (2003). "Climate change and the oil industry—Common problem, different strategies”, Manchester University Press, Manchester, UK, pp. 12-13.

Bouzarovski, S. (2018). “Energy Poverty-(Dis)Assembling Europe’s Infrastructural Divide”, Palgrave Macmillan, Springer International Publishing AG, Cham, Switzerland, pp. 1-2.

Casazza, J., Delea, F. (2003). "Understanding Electric Power Systems-An Overview of the Technology and the Marketplace”, IEEE Press, John Wiley \& Sons, Hoboken, USA, p. 8.

Errera, S., Brown, S. L. (2002.). "Fundamentals of Trading Energy Futures \& Options, Second Edition”, PennWell Corporation, Tulsa, USA, pp. 169-170.

Fernandes, A., Victor, R. (2015). "Environmental Law and the Oil, Gas and Biofuel Industries” in de Alencar Xavier, Y. M. (ed): "Energy Law in Brazil-Oil, Gas and Biofuels”, Springer International Publishing, Cham, Switzerland, p. 158.

Franjić, S. (2015). “Croatian Strategy of Energy Development, European Union, Climate Change and the Environment Protection”, Journal of Energy and Power Sources, Vol. 2, No. 7, Rowland Heights, USA, July 2015, pp. 268-273.

Franjić, S. (2016a). "Legal Regulations of European Energy Policy in Croatia”, Applied Engineering Letters, Novi Sad, Serbia, Vol. 1, No. 2, pp. 40-45.

Franjić, S. (2016b). "Sigurna opskrba energijom” (Secure energy supply), PLIN2016, Sept. 28th-30th, 2016, Osijek, Croatia, pp. 53-58.

Franjić, S. (2017). "Učinkovita uporaba energije” (Efficient use of energy), PLIN2017, Sept. 27th-29th, 2017, Osijek, Croatia, pp. 139-145.

Franjić, S. (2018). "Energy Poverty in Croatia", 7. Međunarodni znanstveni simpozij "Gospodarstvo istočne Hrvatske-vizija i razvoj"/7th International Scientific Symposium "Economy of eastern Croatia—vision and growth", Sveučilište Josipa Jurja Strossmayera u Osijeku, Ekonomski fakultet u Osijeku, May 24th-26th, 2018, Osijek, Croatia, pp. 528-536.

Fusaro, P. C. (2010). “The Global Challenge for Energy and Environmental Investment” in Kramer, A. S.; Fusaro, P. C. (eds): "Energy and Environmental Project Finance Law and Taxation-New Investment Techniques”, Oxford University Press, Oxford, UK, p. 1.

Haal, C. A. S., Klitgaard, K. (2018). "Energy and the Wealth of Nations-An Introduction to Biophysical Economics”, Second Edition, Springer International Publishing AG, Cham, Switzerland, p. 481.

Huber, B. R. (2018). "Paying for Energy" in Mathis, K., Huber, B. R., "Energy Law and Economics”, Springer International Publishing AG, Cham, Switzerland, pp. 138-139.

Kamphof, R., Bonenkamp, T., Selleslaghs, J., Hosli, M. O. (2017). "External competences in energy and climate change” in Leal-Arcas, R., Wouters, J. (eds): "Research Handbook on EU Energy Law and Policy”, Edward Elgar Publishing Limited, Cheltenham, UK, pp. 30-31.

Luft, G., Korin, A. (2009). “Energy Security: In the Eyes of the Beholder” in Luft, G.; Korin, A. (eds): “Energy Security 
Challenges for the 21st Century—A Reference Handbook”, ABC-CLIO, Santa Barbara, USA, p. 6.

Pereira, R., Jourdain, C. (2012). "International and EU Climate Change Law” in Makuch, K. E. (ed): "Environmental and Energy Law”, Wiley-Blackwell, John Wiley \& Sons, Chichester, UK, p. 141.

Perner, J., Riechmann, C. (2015). “Energy Market Design with Capacity Mechanisms” in Hancher, L., De Hautecloque, A., Sadowska, M. (eds): “Capacity Mechanisms in EU Energy Markets-Law, Policy, and Economics”, Oxford University Press, Oxford, UK, p. 72.

Proedrou, F. (2012). "EU Energy Security in the Gas Sector-Evolving Dynamics, Policy Dilemmas and Prospects", Ashgate Publishing Limited, Farnham, UK, p. 41.

Richter, B. (2010). "Beyond Smoke and Mirrors-Climate Change and Energy in the 21st Century", Cambridge University Press, Cambridge, UK, pp. 50-51.

Sovacool, B. K., Drupady, I. M. (2012). "Energy Access, Poverty, and Development-The Governance of Small-Scale Renewable Energy in Developing Asia”, Ashgate Publishing Limited, Farnham, UK, p. 1.

Šimundić, S., Franjić, S. (2015). "Pravna regulativa u elektrotehnici i računarstvu" (Legal regulations in electrical engineering and computer science), Sveučilište Josipa Jurja Strossmayera u Osijeku-Elektrotehnički fakultet u Osijeku, Osijek, Croatia, p. 88.

Talus, K. (2016). “Introduction to EU Energy Law”, Oxford University Press, Oxford, UK, p. 127.

Weber, G. (2018). "Sustainability and Energy Management-Innovative and Responsible Business Practices for Sustainable Energy Strategies of Enterprises in Relation with CSR”, Springer Fachmedien, Wiesbaden, Germany, p. 51. 